\title{
Pembuatan Susu Kedelai Organik Sebagai Salah Satu Peluang Bisnis Penambah Penghasilan Keluarga
}

\section{Mayarni $^{1}$, Susanti Murwitaningsih ${ }^{2}$, Yuni Yulianti ${ }^{3}$}

${ }^{123}$ Universitas Muhammadiyah Prof. Dr.Hamka,

E-mail: mayarni@uhamka.ac.id

\begin{tabular}{ll}
\hline Article History: & Abstrak: \\
Received: Desember & Pembuatan susu kedelai organik bertujuan \\
Revised: Desember & untuk memberikan keterampilan siswa SMA \\
Accepted: Desember & berwirausaha. Terutama siswa SMA yang \\
Available online: Desember & akan lulus. Metode yang digunakan \\
& demonstrasi yang selanjutnya para peserta \\
Kata Kunci: & adanya pandemi maka demonstrasi \\
mahasiswa, masyarakat, & berlangsung secara online hingga mampu \\
susu kedelai organik, siswa & menjangkau banyak peserta termasuk \\
SMA, wirausaha & masyarakat setempat dan mahasiswa. \\
& Pemilihan kegiatan pembuatan susu kedelai \\
& karena berdasarkan survei hampir semua \\
& kalangan menyukai susu kedelai. Alasan \\
& pemilihan kedelai organik, usaha ini masih \\
& belum ditemukan, sehingga dapat menjadi \\
& peluang bisnis yang baik dalam berwirausaha. \\
& Siswa SMA yang umumnya sedikit \\
memperoleh keterampilan dibanding siswa & SMK, itu alasan kedua diberikan bimbingan \\
ini, terlebih kegiatan ini diberikan saat siswa & SMA akan lulus sekolah. Hasil akhir kegiatan \\
ini yang sudah melaporkan terbentuk tiga & pengusaha susu kedelai dua dari masyarakat \\
satu dari mahasiswa. Namun kesulitan \\
memperoleh dan mahalnya harga kedelai \\
organik, yang tidak sebanding dengan harga \\
jual, para pengusaha jadi beralih \\
menggunakan kedelai non organik.
\end{tabular}




\section{Pendahuluan}

Kegiatan ini diberikan pada kelas 12 salah satu SMA swasta Jakarta Timur, Mahasiswa dan Masyarakat setempat. Siswa ini adalah siswa santri wanita. Permasalahan yang timbul sekarang adalah siswa kelas 12 akan lulus dan siap terjun di masyarakat, apabila tidak melanjutkan ke jenjang perguruan tinggi. Oleh karena itu sangat baik bila dibekali dengan berbagai keterampilan. Salah satunya adalah workshop pembuatan susu kedelai organik. Kegiatan ini baik siswa, mahasiswa dan masyarakat diharapkan dapat membantu secara ekonom. Zaman sekarang hidup penuh persaingan, hanya yang kreatif yang mampu hidup bersaing di masyarakat. Salah satu kemampuan yang harus dimiliki oleh SDM adalah mampu berpikir secara kritis dan kreatif serta keinginan untuk bekerja sama yang efektif (Mayarni \& Hazimah, 2020; Mayarni \& Yulianti, 2020). Selain itu pengabdian masyarakat ini ditujukan sebagai ajang promosi dan pendekatan kampus pada masyarakat. Diharapkan dengan diadakannya kegiatan di kelas 12 SMA, kami dari TIM berharap semakin banyak peserta semakin banyak yang memulai usaha walaupun sekedar usaha sampingan sehingga dapat menambah penghasilan keluarga. Harapan yang lain diharapkan semakin banyak produksi minuman sehat semakin udah masyarakat mendapatkannya, agar para masyarakat yang mengkonsumsi minuman sehat akan berdampak terhadap kesehatan masyarakat di sekelilingnya. Menurut salah satu penelitian isoflavone yang terkandung dalam susu kedelai bila diminum 100mg selama 4 bulan dapat menurunkan perubahan gejala menopause dan dapat meningkatkan kesehatan jantung, dapat menurunkan kolesterol total dan menurunkan lipoprotein density (Han et al., 2002). Umumnya kedelai dimanfaatkan masyarakat sebagai sumber gizi dan protein, sebab murah juga mudah didapatkan (Winarsi, Purwanto, \& Dwiyanti, 2010). Susu kedelai merupakan salah satu upaya untuk perbaikan gizi, karena mengandung protein hewani dan nabati. (Arianty \& Masyhura, 2019)

Menurut penelitian lain mengungkapkan bahwa kedelai itu memberikan manfaat kesehatan, mengurangi penyakit kardiovaskular, mengurangi gejala menopause, menurunkan berat badan, radang sendi, dan fungsi otak. Kedelai mengandung phytochemical diantaranya isoflavon, 
saponin, dan phy-tosterol untuk meningkatkan kesehatan, susu kedelai adalah suplemen ideal yang bebas kolesterol untuk kardiovaskular. Susu kedelai yang difermentasi bagus sebagai sebagai anti ACE, anti oksidatif anti kanker (Vij, Hati, \& Yadav, 2011). Manfaat kesehatan dalam kedelai dikaitkan dengan isoflavonoid yang dapat mendukung kemopreventif sel yang sakit dan juga mengandung fitokimia fenolik utama yang ditemukan dalam susu kedelai (McCue \& Shetty, 2004)

Dari beberapa referensi terkemuka diatas dapat disimpulkan susu kedelai mengandung isoflavonoid, saponin, fitokimia, yang semuanya itu bermanfaat bagi kesehatan tubuh seperti memperbaiki kerusakan sel, mencegah penyakit kanker, menurunkan gejala menopause dan baik untuk orang beresiko penyakit jantung karena tidak mengandung kolesterol.

Identifikasi permasalahan yang dihadapi mitra diantaranya adalah mitra merupakan siswa yang akan segera lulus dari Pendidikan SMA. Tidak semua siswa SMA melanjutkan ke jenjang perguruan tinggi, sebagian dari mereka akan terjun hidup di masyarakat. Untuk itu perlu keterampilan yang dapat mendukung kelulusan hidup di masyarakat. Salah satu keterampilan yang mungkin adalah membuat susu kedelai. Susu kedelai ini cukup banyak peminatnya namun masih jarang di sekitar ini dijual, oleh karena itu bisa menjadi alternatif keterampilan yang dapat menghasilkan secara ekonomi. Selain itu permasalahan lain adalah prodi Pendidikan Biologi mahasiswanya tidak terlalu banyak tahun demi tahunnya, maka tim berharap ini juga sebagai ajang promosi agar lebih banyak siswa SMA As-Syafi'yah masuk di prodi Pendidikan Biologi. Selain itu berdasarkan hasil survei lebih dari seratus orang maka 79 persen belum pernah membuat susu kedelai. Padahal ini merupakan peluang bisnis yang cukup menguntungkan.

\section{Metode}

Kegiatan ini direncanakan sebelum pandemi, namun saat kegiatan berlangsung kondisi dalam keadaan pandemi oleh karena itu bentuk kegiatan diubah menjadi online. Kegiatan ini diawal direncanakan di sebuah SMA swasta Jakarta Timur dan ditujukan untuk kelas 3 SMA. Tujuan diberikan untuk kelas tiga agar berguna bagi mereka sebagai bekal 
wirausaha terutama bagi mereka yang tidak lanjut studi ke perguruan tinggi. Namun karena pelaksanaan terjadi saat pandemi, maka bentuk kegiatan diubah menjadi online. Hal ini menguntungkan karena dapat menjangkau peserta lebih luas dan lebih banyak.

Pelaksanaan kegiatan, menggunakan online zoom sehingga dapat menjangkau banyak peserta. Akhirnya kegiatan diikuti oleh siswa SMA, masyarakat sekitar dan mahasiswa pendidikan Biologi Uhamka. Kegiatan ini terlaksana 20 sampai 22 Agustus 2020, banyaknya waktu yang digunakan diperlukan untuk membuat produk contoh dan membuat produk setengah jadi serta untuk praktek kegiatan menggunakan online zoom. Demonstrasi kegiatan berlangsung tanggal 20 Agustus 2020.

Berdasarkan hasil survei, siswa SMA sangat memerlukan keterampilan sebagai bekal berwirausaha, terutama pada siswa yang akan lulus. Agar dapat di jadikan bekal dalam terjun di masyarakat.
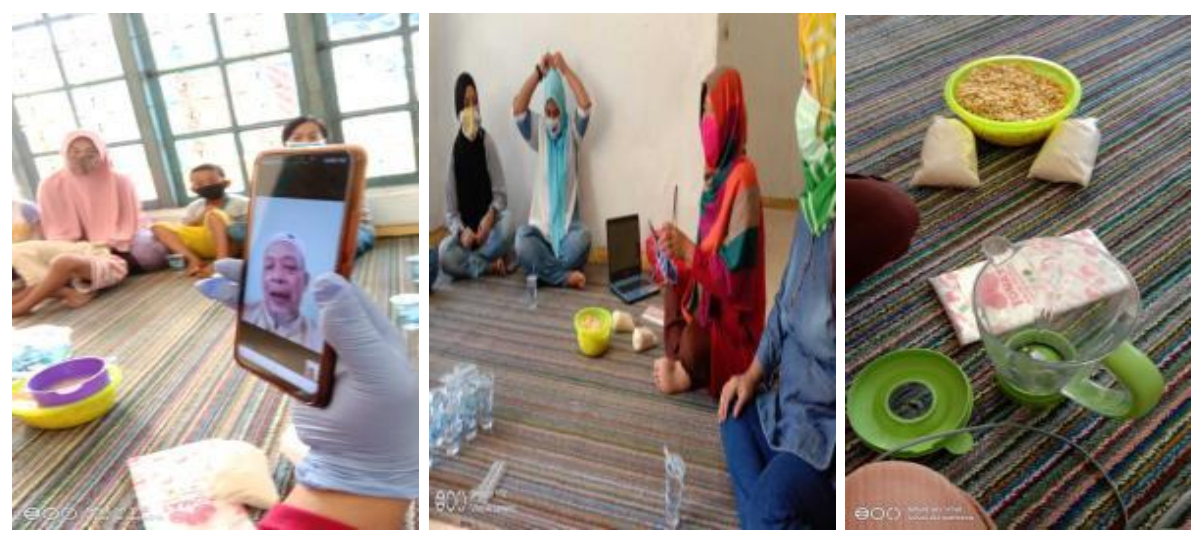

Gambar 1. Foto-foto saat kegiatan

Gambar sebelah kiri, sambutan dari kepala SMA As-Syafi'yah, tengah memperlihatkan kegiatan menggunakan onlane zoom dan kanan gambar sebagian alat dan bahan.

Langkah pelaksanaan adalah sebagai berikut:

Pertama, melakukan diskusi bersama Pimpinan sebuah SMA AsSyafi'yah, dan juga berdiskusi dengan ketua RT 03/RW 11 Jati Rahayu 
Bekasi serta mengkomunikasikan kegiatan dengan mahasiswa Biologi Uhamka. Diperlukan waktu yang tepat karena kegiatan berlangsung hampir berbarengan dengan Penilaian Akhir Semester dan ujian kelulusan. Oleh karena itu perlu kesepakatan yang matang agar kegiatan terlaksana dengan baik dan bermanfaat.

Kedua, mempersiapkan alat dan bahan. berupa kompor gas, panci, saringan dari kain yang cukup rapat, blender, botol kemasan, sendok pengaduk. gula putih dan kedelai.

Ketiga, membuat produk contoh yang akan diberikan kepada para peserta saat kegiatan berlangsung dengan cara : merendam kedelai kurang lebih 8 jam, lalu bersihkan kulit arinya, cuci bersih, blender dengan air lalu saring menggunakan kain rapat setelah itu direbus dengan api kecil serta diberi gula putih. Kedelai, air dan gula dengan perbandingan $1 / 2 \mathrm{~kg}$ kedelai sembilan liter air dan $1 \mathrm{~kg}$ gula putih. Perebusan dilakukan dengan api kecil sampai matang sambal terus diaduk agar tidak terjadi penggumpalan.

Keempat, hari kegiatan berlangsung dilakukan demonstrasi yang dihadiri sebagian warga setempat. Sedangkan siswa dan mahasiswa menghadiri melalui online zoom.

Kegiatan dilaksanakan secara daring akibat adanya wabah pandemi. Oleh karena itu kami memberi peluang untuk meluaskan acara ini dengan mengikutsertakan mahasiswa dan masyarakat setempat. Acara ini dihadiri oleh lebih dari 100 orang. Kedelai organik, dan botol kemasan diperoleh secara online. Cara memasak susu kedelai ini hanya dengan diaduk kurang lebih 1 jam dan diberi gula sesuai selera, saat memasak susu kedelai ini harus terus diaduk agar tidak terjadi penggumpalan yang akan merusak susu kedelai. Setelah matang susu kedelai diangkat dan dibiarkan sampai agak dingin. Setelah dingin dimasukan kedalam botol kemasan dan beri label bila perlu, susu kedelai siap dipasarkan dalam kondisi dingin atau panas. Pembuatan susu kedelai ini diharapkan memberi peluang bisnis bagi para peserta. Selain itu diharapkan para penikmat susu kedelai mendapatkan manfaat yang cukup bagus karena susu kedelai tidak mengandung lemak tak jenuh. 
Menurut sebuah penelitian mengatakan bahwa perbandingan susu kedelai, susu sapi dalam $100 \mathrm{~g}$, untuk susu kedelai mengandung air 88,6 g protein 4,4 g untuk susu sapi air 88,6 dan protein 2,9 dalam \% (Jain, 1988).Hal tersebut menjelaskan bahwa konsumsi susu kedelai lebih baik ketimbang konsumsi susu sapi dalam asupan protein (Jain, 1988). Penelitian lain membandingkan antara susu kedelai dan susu kambing. Susu kedelai mengandung lemak 4,67 gram lemak, 0,52 asam lemak, 3,18 serat, 6,73 protein. Sedangkan susu sapi mengandung 8,15 gram lemak, 5,07 asam lemak, 0,00 serat, 8,02 protein (Hajirostamloo, 2009). Dapat diartikan bahwa susu kedelai tidak jauh tertinggal ketimbang susu sapi, tetapi mempunyai kelebihan seperti memiliki serat yang berguna bagi pencernaan yang tidak dimiliki oleh susu sapi serta kandungan protein yang cukup tinggi serta susu kedelai tidak mengandung lemak jenuh dimana lemak jenuh ini dapat menambah kolesterol dalam tubuh kita. Lemak jenuh umumnya dimiliki oleh hewani, lemak ini susah dicerna dan dapat meningkatkan kolesterol dalam tubuh. Selain itu konsumsi protein kedelai lebih baik dari pada protein hewani secara signifikan menurunkan kadar serum kolesterol total, kolesterol LDL dan trigliserida tanpa mempengaruhi LDL apabila dibuat yogurt. Yogurt susu kedelai mempunyai banyak manfaat mengurangi radang sendi, mengurangi penyakit kardiovaskuler, mengurangi penyakit menopause, menurunkan berat badan. Mengandung fitokimia seperti isoflavon, saponin, fitosterol. yang meningkatkan kesehatan (Vij et al., 2011). Manfaat mengkonsumsi susu kedelai apalagi bila dijadikan soygurt akan sangat baik untuk kesehatan karena dapat memperlambat osteoporosis, menurunkan kolesterol, mengurangi radang sendi, menurunkan berat badan dan dapat mengurangi resiko penyakit jantung, mengandung isoflavon, saponin dan fitosterol yang sangat baik untuk meningkatkan kesehatan.

Sebuah penelitian menyampaikan didalam membuat susu kedelai penambahan air 1:10 adalah yang terbaik dalam menghasilkan susu kedelai (Picauly et al., 2015). Namun dalam kegiatan ini dimodifikasi menjadi 500g ditambah air 9 liter dan $1 \mathrm{~kg}$ gula, ini dilakukan untuk meminimalkan bau kedelai yang khas. 


\section{Hasil}

Kegiatan ini dihadiri 100 orang peserta, dari 100 orang peserta yang sudah melaporkan tiga keluarga yang betul-betul memulai usaha susu kedelai karena terinspirasi kegiatan ini. Satu dari mahasiswa dua dari masyarakat. Para pengusaha rumahan baru ini dua diantaranya melakukan usaha susu kedelai sungguhan agar dapat tambahan penghasilan untuk keperluan keluarga. Pengusaha ketiga masih coba-coba namun tetap berjualan walau membuatnya tidak setiap hari. Menurut ungkapan para pembuat susu kedelai ini, mereka berterima kasih sudah diajarkan sehingga terinspirasi dan mulai usaha dengan menitipkan ke setiap warung. Mereka menyampaikan bahwa pembuatan susu kedelai ini cukup menguntungkan. Walau penjualanya baru dengan cara menitipkan di warung tetangga. Susu kedelai merupakan peluang yang bagus berwirausaha, selain menguntungkan secara pribadi juga bagus untuk kesehatan para konsumtif.

Menurut sebuah artikel, susu kedelai tidak hanya diminum sebagai susu kedelai namun bisa diolah menjadi yogurt atau yang terkenal dengan nama soygurt, namun pada pembuatan ini untuk mendukung pertumbuhan lactobacillus bulgaricus perlu penambahan susu skim. Susu skim ini juga diperlukan untuk membuat yogurt yang dihasilkan lebih kental (Gulo, 2006).

Hasil analisis angket terhadap 100 orang masyarakat sasaran dengan pertanyaan yang ditampilkan jawabanya dalam persen adalah sebagai berikut: "Apakah anda sudah pernah membuat susu kedelai". 79,2 belum, 7,9 sudah, dan 12,9 sudah pernah sudah sangat lama sekali. Hal ini menindikasikan ada peluang tambahan yang akan ikut meminum yaitu 79,2 persen, ini dimungkinkan karena sifat seseorang yang ingin mencoba seatu yang mereka anggap baru bagi mereka sendiri. Pertanyaan berikut "Apakah anda menyukai susu kedelai". 52,5 sangat suka, 38,6 tidak terlalu suka dan 8,9 tidak suka sama sekali. Hal ini dapat diartikan 52,5 persen sangat suka cukup banyak yang sangat suka bila dilihat dari hasil persentase. Pertanyaan berikut "Apakah ditempat anda ada yang menjual susu kedelai organik". 62,4 tidak ada, 17,8 ada hanya satu, 19,8 ada banyak. Dapat diartikan lebih dari 50 persen dari 100 orang yang di survei di sekitar rumah mereka tidak ada yang menjual susu kedelai terutama susu kedelai organik. Pertanyaan berikut 
adalah "Susu kedelai mengandung isoflavone berguna untuk mencegah penyakit kanker, penyakit jantung dan osteoforosis apakah anda sudah mengetahuinya".84,2 belum dan baru mengetahui sekarang 15,8 sudah mengetahui untuk itu saya memilih susu kedelai. Hal ini bila diadakan promosi berdasarkan manfaat ada 84,2 persen dari 100 yang di survei akan tertarik meminum susu kedelai karena mengandung manfaat yang bagus untuk kesehatan. Bila disimpulkan dari beberapa jawaban angket ini membuat susu kedelai merupakan peluang yang cukup baik dalam berwirausaha. Dan yang perlu ditambahkan agar wirausaha ini berjalan lebih lancar adalah promosi yang menarik dalam menyampaikan manfaat yang berkaitan dengan kesehatan. Hal ini berkaitan dengan salah satu pernyataan dari sebuah artikel yang menyampaikan bahwa; Kesehatan sangat penting bagi manusia, karena tanpa kesehatan yang baik, setiap manusia akan sulit dalam melaksanakan aktivitasnya sehari-hari(Prasetyo, 2015).

\section{Kesimpulan}

Susu kedelai dari beberapa penelitian selain mengandung tinggi protein ini sangat baik dikonsumsi karena dapat meningkatkan kesehatan seperti menurunkan berat badan, mencegah osteoporosis, menurunkan kolesterol. Namun masalah yang terjadi untuk sebagian kecil masyarakat mereka tidak suka karena yang khas, ini mungkin bisa diatasi dengan memberikan tambahan rasa lainnya yang diperbolehkan. Selain itu susu kedelai bisa juga dijadikan yogurt yang dikenal dengan istilah Soygurt, dengan cara memadukan susu kedelai dengan susu sapi dengan penambahan starter yang biasa digunakan sebagai starter yogurt. Dalam membuat soy gurt (yogurt susu kedelai) dibutuhkan susu skim sebanyak 6\%, ini diperlukan untuk menambah kekentalan (Gulo, 2006). Pembuatan susu kedelai dilakukan dengan perbandingan $500 \mathrm{~kg}$ kedelai ditambah dengan 9 liter air dan $1 \mathrm{~kg}$ gula. Menghasilkan susu kedelai yang manisnya sedang dan baunya juga samar sehingga bisa dikonsumsi untuk banyak orang termasuk yang tidak menyukai, karena komposisi ini sudah menyamarkan bau khas kedelai.

Melihat dari kenyataan di lapangan bahwa masih banyak para generasi muda yang hanya bersifat konsumtif, maka dalam meningkatkan taraf 
ekonomi bangsa sudah seharusnya dimulai dari hal yang sangat sederhana seperti yang hanya berwirausaha membuat susu kedelai.

\section{Pengakuan}

Kegiatan ini terlaksana karena bantuan berbagai pihak terutama LPPM-UHAMKA,dengan nomor kontrak 0175/11.04.02/2020, dan kami TIM mengucapkan banyak terima kasih atas bantuan yang diberikan baik moril maupun materil.

\section{Daftar Referensi}

Arianty, N., \& Masyhura. (2019). Strategi Pemasaran Susu Kedelai Dalam Upaya Meningkatkan Pendapatan Keluarga. Seminar Nasional Kewirausahaan, 1(1), 257-264. https://doi.org/10.30596/snk.vlil.3620

Gulo, N. (2006). Substitusi Susu Kedelai Dengan Susu Sapi Pada Pembuatan Soyghurt Instan. 4(2), 70-73.

Hajirostamloo, B. (2009). Comparison of nutritional and chemical parameters of soymilk and cow milk. World Academy of Science, Engineering and Technology, 57, 436-438. https://doi.org/10.5281/zenodo.1077072

Han, K. K., Jr., J. M. S., Haidar, M. A., \& Rodrigues, G. (2002). Benefits of soy isoflavone therapeutic regimen on menopausal symptoms.

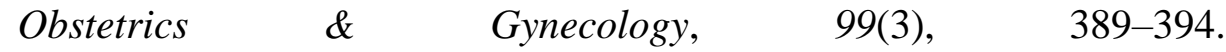
https://doi.org/10.1016/s0029-7844(01)01744-6

Jain, M. (1988). Educating health workers and villagers on the dietary uses of soy foods in Madhya Pradesh, India. Food \& Nutrition Bulletin, 10(4), 41-44. https://doi.org/10.1177/156482658801000421

Mayarni, \& Hazimah, D. (2020). Relationship between Analytical Thinking Ability and Creative Thinking Ability in Ecological Materials. Ice Stem, 28-36.

Mayarni, M., \& Yulianti, Y. (2020). Hubungan antara Kemampuan Berpikir Kritis dengan Kemampuan Berpikir Kreatif Siswa pada Materi Ekologi. PENDIPA Journal of Science Education, 4(3), 39-45. https://doi.org/10.33369/pendipa.4.3.39-45

McCue, P., \& Shetty, K. (2004). Health Benefits of Soy Isoflavonoids and Strategies for Enhancement: A Review. Critical Reviews in Food 
Science and Nutrition, 44(5), 361-367. https://doi.org/10.1080/10408690490509591

Picauly, P., Talahatu, J., \& Mailoa, M. (2015). Pengaruh Penambahan Air Pada Pengolahan Susu Kedelai Effect of Water Addition in the Processing of Soya Milk. AGRITEKNO, Jurnal Teknologi Pertanian, $4(1), 8-13$.

Prasetyo, Y. (2015). Kesadaran Masyarakat Berolahraga Untuk Peningkatan Kesehatan Dan Pembangunan Nasional. Medikora, 11(2), 219-228. https://doi.org/10.21831/medikora.v11i2.2819

Vij, S., Hati, S., \& Yadav, D. (2011). Biofunctionality of Probiotic Soy Yoghurt. Journal Food and Nutrition Sciences, 02(05), 502-509. https://doi.org/10.4236/fns.2011.25073

Winarsi, H., Purwanto, A., \& Dwiyanti, D. H. (2010). Kandungan Protein dan Isoflavon pada Kedelai dan Kecambah Kedelai A Study on Protein and Isoflavone Content of the Soy and Soy Germ. 15(2), 181-187. https://doi.org/https://doi.org/10.24002/biota.v15i2.2696 